Available online at : http://journal.unj.ac.id/unj/index.php/gjik

Gladi Jurnal Ilmu Keolahragaan 07 (02) 2013, 61 - 66

Permalink/DOI: https://doi.org/10.21009/GJIK.081.05

\title{
MODEL PEMBELAJARAN KETERAMPILAN LARI GAWANG (A.D.L) BERBASIS PERMAINAN UNTUK SISWA SEKOLAH MENENGAH ATAS (SMA)
}

\section{Ayu Dyah Lubena ${ }^{1}$}

\begin{abstract}
Abstrak
Penelitian ini dilakukan untuk mengembangkan keterampilan lari gawang bagi Siswa Sekolah Menengah Atas (SMA). Penelitian dan pengembangan ini menggunakan pendekatan kualitatif dan kuantitatif dengan menggunakan metode penelitian pengembangan Research \& Development $(R \& D)$. Instrumen yang digunakan dalam penelitian dan pengembangan ini adalah angket kuesioner serta instrumen psikomotorik keterampilan lari gawang yang digunakan untuk mengumpulkan data pada tahap: (1) desain produk (2) perencanaan pengembangan model (3) validasi, evaluasi, dan revisi model. Dalam melihat hasil efektifitas model digunakan uji statistik dengan menggunakan rumus uji t berkorelasi dengan taraf signifikan $\alpha=0,05$. Hasil perhitungan diperoleh nilai t-hitung $-52,597$ sedangkan t-tabel 1,669 dan taraf signifikan sebesar 0,000 , berdasarkan dari data yang diperoleh dapat disimpulkan bahwa: model pembelajaran keterampilan lari gawang (A.D.L) berbasis permainan bagi Siswa Sekolah Menengah Atas (SMA) layak serta efektif dalam meningkatkan keterampilan lari gawang untuk Siswa Sekolah Menengah Atas.
\end{abstract}

Kata kunci: keterampilan; lari gawang; permainan

\section{PENDAHULUAN}

Peran utama pembelajaran dari

Pendidikan Jasmani sendiri adalah mengembangkan

keterampilan,

pengelolaan diri dalam upaya

pengembangan dan pemeliharaan

kebugaran jasmani serta pola hidup sehat melalui berbagai aktivitas jasmani dan olahraga yang terpilih. Untuk itu dalam melaksanakan pembelajarannya dapat saja menggunakan berbagai macam variasi dan model, artinya Pendidikan Jasmani tidak menuntut adanya prestasi dalam suatu cabang olahraga yang diajarkan.

Namun dalam pelaksanaannya masih banyak guru yang kurang kreatif dalam memberikan pembelajaran lari gawang, hal ini membuat materi ini kurang begitu diminati oleh siswa. Untuk mengatasi hal tersebut harus ada upaya yang mesti dilakukan yakni dengan memberikan variasi-variasi pembelajaran dengan cara pengembangan model lari gawang A.D.L berbasis permainan untuk Siswa Menengah Atas (SMA).

Keterampilan pada lari gawang dibutuhkan suatu proses dengan mengembangkan keterampilan motorik individu tersebut dengan tidak terlepas dari pertimbangan faktor usia. Proses yang dimaksud adalah suatu tahapan pembelajaran gerak melalui proses belajar (Richard A. Magil, 2011).

Belajar dapat dikatakan sebuah proses yang kompleks yang terjadi pada semua

\footnotetext{
${ }^{1}$ Ayu Dyah Lubena adalah guru pendidikan jasmani di SMAN 3 Kota Bekasi
} 
orang dan berlangsung seumur hidup, sejak masih bayi bahkan dalam kandungan hingga liang lahat (Eveline Siregar dan Haritini Nara, 2010). Kemudian dijelaskan lebih lanjut bahwa belajar dimaknai dengan sebuah proses perubahan tingkah laku sebagai akibat adanya interaksi antara individu dengan lingkungannya (Husdarta dan Yudha M. Saputra, 2013)

Adapun ciri-ciri dari belajar adalah adanya kemampuan baru atau perubahan (perubahan tersebut dapat berupa pengetahuan (kognitif), keterampilan (psikomotorik), maupun nilai dari sikap (afektif)), selanjutnya perubahan itu tidak berlangsung sesaat saja melainkan menetap atau dapat disimpan, perubahan itu tidak terjadi begitu saja melainkan harus dengan usaha, perubahan tidak semata-mata disebabkan oleh pertumbuhan fisik, atau kedewasaan, tidak karena kelelahan, penyakit atau pengaruh obat-obatan.

Untuk itu pada dasarnya keterampilan motorik terus berkembang sejalan dengan kematangan saraf dan otot anak. Hal ini mengacu pada perubahan yang progresif dalam perilaku gerak, rentang hidup dengan perubahan yang berurutan dan berkaitan dengan usia (Nurturing Early Learners, 2013).

Akan tetapi keterampilan motorik tidak saja di pengaruhi oleh komponen fisik saja, tetapi juga dipengaruhi oleh beberapa ranah, yaitu ranah: motor domain, cognitive domain dan percepsual domain (William $\mathrm{H}$. Edwards, 2011).

Untuk mencapai hasil belajar lari gawang yang menitik beratkan pada ranah psikomotor, yaitu dengan keterampilan gerak. Maka pembelajarannya membutuhkan pengembangan pada teknik dasar dengan menekankannya pada keterampilan gerak. Harapan hasil belajar ini tentunya berupa meningkatnya keterampilan gerak siswa dalam melakukan lari gawang.

Lari gawang merupakan suatu proses lari cepat (sprint) dengan melewati gawang sejumlah 10 buah gawang dengan ketinggian tertentu dan dipasang didalam lintasan (Eddy, 2011). Berdasarkan peraturan Internasional nomor lari gawang terdiri atas lari gawang 110 meter putra, dan 100 meter putri serta 400 meter putra dan putri (International Association of Athletics Federations, 2015). Dalam pelaksanaan lari gawang terdapat 6 (enam) elemen/ tahapan gerak yang harus dilakukan yakni: start dan lari percepatan menuju gawang pertama, bertolak dan menyerang gawang (tahap topang pertama), melewati gawang (tahap melayang), mendarat setelah melewati gawang (tahap topang kedua), lari sprint diantara gawang - gawang, lari menuju finish (Roberto Bedini, 2012).

Dalam melakukan lari gawang hal yang sangat diperhatikan adalah ketika pada saat fase melewati gawang. Pada fase ini jalur 
ketika melayang harus sedatar mungkin dengan gawang untuk mengefisienkan waktu dan tenaga yang dikeluarkan (Abdel Karim Wahab, 2013).

Untuk mencapai hasil yang maksimal dalam melakukan lari gawang akselerasi dari start menuju ke gawang pertama pelari harus melakukan dengan kecepatan maksimal dan berusaha mencapai 8 (delapan) langkah pertama menuju gawang pertama (Australian Track and Field Coaches Association, 2013).

Dalam melaksanakan keterampilan lari gawang yang efektif seorang guru dapat memberikan berbagai pendekatan agar siswa termotivasi dan tertarik untuk mengikuti pembelajaran. Pada dasarnya karakteristik pada tingkat usia remaja masih mengedepankan unsur bermain dalam setiap prosesnya, hal itu di gunakan untuk membangkitkan rasa berfikir kreatif (Susan Boyle, 2011). Bermain juga dapat diartikan sebagai aktifitas apapun yang dipilih secara bebas, intrinsik, termotivasi dan diarahkan secara pribadi (Jeffrey Goldstein, 2012). Untuk itu pendekatan yang diberikan dalam meningkatkan keterampilan lari gawang menggunakan metode berbentuk permainan agar pembelajaran menjadi lebih menarik, memicu pemikiran yang inovatif dan memberikan keragaman metode pembelajaran sehingga dapat membuat siswa termotivasi dan menimbulkan kesenangan dalam melakukan gerakan lari gawang (Sifa, 2014).

Permainan yang bersifat edukatif dapat berfungsi sebagai ilmu pengetahuan kepada anak melalui proses pemberian pembelajaran bermain sambil belajar, merangsang pengembangan daya pikir, daya cipta, dan bahasa, agar dapat menumbuhkan sikap, mental, serta akhlak yang baik, menciptakan lingkungan bermain yang menarik, memberikan rasa aman, dan menyenangkan, menciptakan kualitas pembelajaran anak-anak (Andang Ismail, 2006).

Rangkaian dalam sebuah permainan harus mengedepankan unsur kesenangan, adanya motivasi intrinsik, proses yang berorientasi, bebas memilih serta terlibat langsung secara aktif (Rachel E. White, 2012). Namun hal ini harus dilakukan dengan menyesuaikannya pada karakteristik anak usia remaja atau setingkat dengan anak SMA.

\section{METODE}

Penelitian dan pengembangan ini menggunakan pendekatan kualitatif dan kuantitatif dengan menggunakan metode penelitian pengembangan Reseach \& Development $(R \& D)$ yang terdiri dari sepuluh langkah dalam penelitian yakni antara lain:

Research and information collecting (2) Planning (3) Development of the 
preliminary from of product (4) Preliminary field testing (5) Main product revision (6) Main field test. (7) Operational product revision (8) Operational field testing (9) Final produk (10) Dissemination and implementation (Borg \& Gall, 2007).

Subjek yang digunakan dalam penelitian ini adalah siswa SMA Negeri 3 Kota Bekasi yang berada di kelas XI dengan total sebanyak 70 siswa dengan rincian kelas XI MIA (Matematika dan Ilmu Alam) 3 sebanyak 34 siswa dan kelas XI MIA (Matematika dan Ilmu Alam) 5 sebanyak 36 orang. Dari subjek inilah nantinya dapat diketahui data-data yang dibutuhkan untuk melihat tingkat keefektifitasan model dalam penerapannya pada pembelajaran keterampilan lari gawang bagi siswa SMA.

\section{HASIL DAN PEMBAHASAN}

Analisis kebutuhan yang dilakukan peneliti pada tanggal 04 Oktober 2016, peneliti melakukan observasi menggunakan instrumen penilaian lari gawang untuk anak Sekolah Menengan Atas dan melakukan wawancara terhadap guru Pendidikan Jasmani yang terdapat pada sekolah tersebut dengan mencari tahu kesulitan yang terdapat dalam menerapkan pembelajaran lari gawang.

Dari hasil tersebut diperoleh beberapa masalah yang ditimbulkan dari penerapan pembelajaran lari gawang di Sekolah
Menengah Atas. Dari hasil tersebut diperoleh bahwa (a) siswa kurang tertarik dalam melakukan pembelajaran lari gawang, (b) siswa mengalami kesulitan dalam melakukan teknik yang terdapat pada lari gawang, (c) guru menyatakan bahwa perlunya variasi-vairasi dalam melakukan pembelajaran lari gawang yang dapat disesuaikan dengan konsep Pendidikan Jasmani sehingga dapat dimasukkan pada setiap proses pembelajaran khususnya bagi pembelajaran lari gawang pada materi atletik.

Setelah melakukan tahap pengumpulan data dan pembuatan draft lari gawang untuk siswa SMA, maka tahap selanjutnya adalah melakukan uji ahli dengan tujuan mendapatkan kelayakan untuk memperoleh validasi model yang telah dibuat dan dinilai langsung oleh ahli yang bersangkutan dibidang cabang olahraga Lari Gawang.

Setelah uji ahli dilaksanakan maka hal yang berikutnya dilakukan adalah mencari hasil dari Pre Test dan hasil dari sesudah diberikannya treatment model dalam melaksanakan keterampilan lari gawang dengan cara pengukuran melalui Post Test. Berikut pemaparan perbandingan hasil antara siswa yang belum diberikan treatment model pembelajaran keterampilan lari gawang (A.D.L) berbasis permainan (pretest) dengan siswa yang 
sudah diberikan treatment model pembelajaran keterampilan lari gawang (A.D.L) berbasis permainan (post test) berdasarkan diagram berikut:

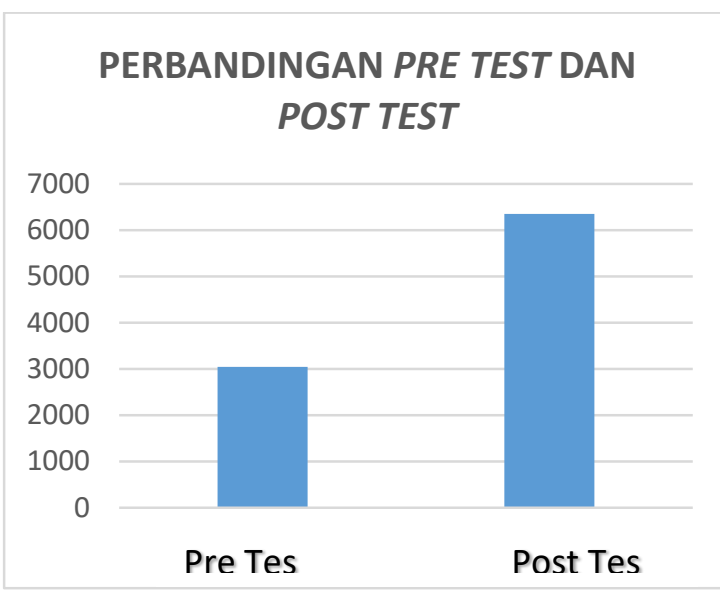

\section{Gambar: Diagram Batang (Uji Coba Kelompok Besar)}

Melihat dari perolehan angka yang sudah didapat dan dijabarkan diatas terdapat peningkatan yang dilakukan saat pretest dilakukan dan post test dilakukan. Artinya dalam pembelajaran lari gawang yang dilakukan siswa berhasil meningkatkan kemampuannya melalui treatment yang diberikan berupa model model pembelajaran lari gawang (A.D.L) berbasis permainan. Perbandingan ini dapat dilihat pada jumlah angka yang didapat pada pre test yakni sebesar 3040 dan pada tahap post test sebesar 6346.

Pada tahap post test jumlah yang didapat meningkat dikarenakan pada tahap ini siswa sudah diberikan treatment berupa model - model pembelajaran lari gawang (A.D.L) yang dibentuk dengan cara bermain sehingga menimbulkan kesenangan terhadap siswa yang mengikutinya. Model-model yang sudah dibuat di telaah, dikaji dan dievaluasi oleh para pakar untuk kemudian diberikan saran berupa bentuk-bentuk kelemahan yang akan terjadi ketika model ini diterapkan. Setelah itu barulah model ini di perbaiki agar mendapatkan hasil yang maksimal. Namun tidak hanya itu saja beberapa keunggulan juga disampaikan oleh beberapa ahli yang dirangkum pada penjabaran dibawah ini. a. Model ini menjadikan siswa lebih aktif. b. Siswa lebih semangat dan antusias dalam melaksanakan pembelajaran lari gawang. c. Tingkat kompetisinya sangat tinggi sehingga memerlukan tenaga dan pikiran yang ekstra namun tidak melupakan kesenangan. d. Media untuk model ini dapat dengan mudah dibuat dan dicari.

Dalam pelaksanaan penelitian ini sudah dilakukan secara maksimal namun tidak dipungkiri jika dalam pelaksanaannya mengalami suatu hambatan dan keterbatasan. Berikut dijelaskan beberapa hambatan dan keterbatasan yang dilakukan oleh peneliti: Dalam pelaksanaan permainannya terdapat beberapa permainan yang membutuhkan prasarana/ lapangan yang cukup luas serta beberapa aspek psikologis juga turut menjadi keterbatasan seperti rasa percaya diri dalam melakukan lompatan dan rasa cemas dalam melaksanakan permainan model - model lari gawang. 
Masih banyak lagi sebenarnya yang menjadi keterbatasan namun dalam hal ini tidak dapat di kontrol oleh peneliti seperti berat badan, tinggi badan, koordinasi gerak dan faktor fisik siswa yang bersangkutan sehingga hal ini dapat menjadi pertimbangan bersama.

\section{KESIMPULAN}

Berdasarkan hasil dari penelitian, data yang dikumpulkan, uji validasi, uji kelompok kecil dan uji kelompok besar (uji efektifitas) dapat dirangkum pada penjelasan berikut ini: 1) Model pembelajaran keterampilan lari gawang (A.D.L) berbasis permainan bagi siswa Sekolah Menegah Atas (SMA) layak dan dapat digunakan untuk meningkatkan keterampilan lari gawang untuk siswa Sekolah Menengah Atas. 2) Dari hasil data dilapangan dan dianalisis secara statistik model pembelajaran keterampilan lari gawang (A.D.L) berbasis permainan bagi siswa Sekolah Menegah Atas (SMA) yang sudah dievaluasi diperoleh data efektifitasnya sehingga model pembelajaran keterampilan lari gawang (A.D.L) berbasis permainan efektif jika dilaksanakan.

\section{DAFTAR PUSTAKA}

Australian Track and Field Coaches Association. Basic Coaching Manual. Little Athletics Queensland, 2013.
Bedini, Roberto. Drills For Top Level Hurdlers: Coaching Pratice. IAAF, 2012.

Boyle, Susan. Teaching Toolkit: An Introduction to Games Based Learning. UCD Teaching And Learning/ Resources, 2011.

Edwards, William H. Motor Learning and Control from theory to Practice. USA: Wadsworth Cangange Learning, 2011.

Goldstein, Jeffrey. Play in Children's Development Health and Well Being. Boulevard de Waterloo: Toy Industries of Europe, 2012.

Ismail, Andang. Education Games. Yogyakarta: Pilar Media, 2006.

International Association Of Athletics Federations. Competition Rules 2016 - 2017. Monaco, 2015.

Learners, Nurturing Early. Motor Skills Development. Republic of Singapore: Ministry Of Education, 2013.

Magill, Richard A. Motor learning and control, concept and application ninth edition. New York : McGraw hill companies, Inc, 2011.

Maksum, Ali. Psikologi Olahraga: Teori dan Aplikasi. Surabaya: Unesa University Press, 2011.

McLennen, Nancy dan Jannine Thompson. Quality Physical Education. United Nations Educational, Scientific, and Cultural Organization, 2015.

Meredith D. Gall, Joyce P. Gall. Walter R. Borg. Eighth Edition Educational Research. NewYork, 2007. 
M.E.,Winarno. Metodologi Penelitian Dalam Pendidikan Jasmani, Malang: Media Cakrawala Utama Press, 2011.

Mukrimah, Sifa Siti. 53 Metode Belajar dan Pembelajaran Plus Aplikasinya. Bandung: Business Management of Education Indonesian University of Education Bumi Siliwangi, 2014.

Purnomo, Eddy dan Dapan. Dasar-Dasar Gerak Atletik. Yogyakarta: Alfamedia, 2011.

Siregar, Eveline dan Haritini Nara. Teori Belajar dan Pembelajaran. Bogor: Ghalia Indonesia, 2010.
Sugiyono. Statistika Untuk Penelitian. Bandung: Alfabeta, 2014

Tangkudung, James dan Wahyuningtias. Kepelatihan Olahraga: Pembinaan Prestasi Olahraga Edisi II. Jakarta: Cerdas Jaya, 2012.

Wahab, Abdel Karim. High Hurdles: A Methodical Approach For Develoving High Hurdles. US For Track \& Field and Cross Country, 2013.

White, Rachel. E. The Power of Play: A Research Summary on Play and Learning. St. Paul: Minnesota Children's Museum Smart Play, 2012. 